\title{
Toward a Ukrainian Feminist Poetics: The Last Soviet Poetry of Iryna Zhylenko, Natalka Bilotserkivets, and Oksana Zabuzhko (1985-1991)
}

\author{
Sandra Joy Russell ${ }^{1 *}$
}

Published: September 8, 2020

\begin{abstract}
Ukrainian feminisms, and East European feminisms more generally, have often been evaluated in relation to those of the so-called West, wherein Western feminisms are (often implicitly) viewed as progressive, and those of Eastern Europe are seen as underdeveloped and/or emerging only after independence. This article resists such neocolonial framings by arguing that the poetic contributions of Ukrainian women writers in the period of perestroika (1985-1991) holds significance for understanding a longer Ukrainian feminist genealogy. As the 1980s brought forth new political and ecological realities, especially the Chornobyl (Chernobyl) explosion in 1986, the stakes of this shifting articulation of nationhood became especially high for women, as the concerns were tied directly to women's sexual and reproductive bodies and futures. To that end, this article positions the work of Iryna Zhylenko (1941-2013), Natalka Bilotserkivets (1954-) and Oksana Zabuzhko (1960-) during perestroika as integral to the emergence of a more visibly subversive feminist rhetoric in Ukraine. While not always 'feminist' in name, women's perestroika poetics, specifically through their representations of embodiment, yielded sharper and more vulnerable articulations of their gendered subjectivities, including the performances of sexual, maternal, and national identities.
\end{abstract}

Keywords: Ukraine, perestroika, glasnost, Cold War, women, feminism, Soviet Union, USSR, Chernobyl, poetry, embodiment, gender, nation, transnational feminisms

Let's keep records. At least those of our own feelings. Let's hope they will create a different time'-Oksana Zabuzhko

\section{INTRODUCTION: GENDERING POETIC EPISTEMOLOGIES}

In a 1995 essay, the poet and scholar Oksana Zabuzhko, reflecting on her generation of writers' new position in Ukraine's literary history, remarks that:

The 'New Wave,' the generation where I belong, is actually the first one after the last six decades that is freed from the obligation 'to save the nation' (Zabuzhko, 1995: 275).

Her observation refers to the ways in which Ukrainian-language poetry and literature throughout much of Soviet history was often a dissident act, and the production of which risked exile, labour camps, or death. Moreover, Zabuzhko's sentiment gestures at the belief, explicitly or implicitly, that intellectual freedom emerges with the presence of a sovereign nation, wherein writers no longer bear the burden of its defence. Yet the murkiness of Ukrainian poetry's relationship with the national idea—as she would come to find out — has remained, however transformed. The last Soviet Ukrainian poets, Zabuzhko among them, were, in many ways, the first to undertake this new vision of nation. As the 1980s brought new political and ecological realities, especially the Chornobyl ${ }^{1}$ explosion in 1986, the stakes of this shifting articulation of nationhood became especially high for women, as the concerns were tied directly to women's sexual and reproductive bodies and futures.

${ }^{1}$ As I am speaking specifically about the Ukrainian context, I use the Ukrainian transliteration 'Chornobyl' rather than the Russian 'Chernobyl'. 
To highlight this changing discourse, I foreground the work of three Ukrainian poets writing during the late Soviet period of perestroika (1985-1991):² Iryna Zhylenko (1941-2013), who began her career with the 'sixtiers' ('shistdesyatnyky') group of poets, Natalka Bilotserkivets (1954-) who began publishing her poetry in the late 1970s, and Oksana Zabuzhko (1960-), who emerged with the 'eightiers' ('visimdesiatnyky'), or what Tamara Hundorova (2019) calls 'the post-Chornobyl generation.' While Zhylenko was an integral part of the Ukrainian literary underground of the 1960s and 1970s, Zabuzhko was one of the foremost writers responsible for bringing the underground to the aboveground during perestroika in the late 1980s. Moreover, I include an intergenerational framing, I emphasise the extent to which the poetry of the late 1980s built on the contributions of previous generations of writers. By centralising the works of Zhylenko, Bilotserkivets, and Zabuzhko during this period, I position this period as a vital contribution within a longer genealogy of Ukrainian women's poetry, marking a shift toward a more visibly subversive feminist rhetoric - one that has become even more perceptible in the post-Soviet period. ${ }^{3}$ This visibility has to do with what Hundorova (2001) refers to as, 'the idea of a national renaissance' that emerges in the 1990s following independence wherein questions of nation, modernity, and identity came to the forefront. Scholars including Hundorova (2019), Michael M. Naydan (2006), and Larissa M. L. Z. Onyshkevych (1993) have productively addressed the significance of Ukraine's literary cultures throughout the late twentieth century, particularly the movement toward a more postmodern aesthetic in the 1990s. However, there has not been substantial exploration of their gendered component, and particularly with regard to the 1980s, wherein political and cultural shifts initiated by perestroika and glasnost evoked new questions of nation and identity.

Secondly, I argue that the transitional period of perestroika holds significance for understanding how Western constructions of a 'second world woman' have often, and perhaps unintentionally, allowed for singular and uncomplicated representations of Eastern European women's experiences, thus contributing to neocolonialist frameworks for considering gender and feminist thought in a post-socialist, and especially post-Soviet, context. Throughout Ukraine's efforts toward democratisation and liberalisation the discourses around gender have shifted. Yet, considering this, I resist latent Cold War narratives that have, often implicitly, identified Western feminist discourse as paradigmatic of progress, as such assumptions risk propagating neocolonial framings of non-Western feminism(s). In so doing, I draw from Chandra Talpade Mohanty's (1997) discussion of 'third world difference,' wherein she challenges monolithic constructions of a 'third world woman.' Likewise, through my exploration of Ukrainian women's poetry, I assess the extent to which, through the inclusion of subversive, and even erotic language, it can challenge assumptions about a similarly monolithic 'second world woman', 5 one who has emerged as a personification of Cold War rhetoric, often reliant on the theoretical tools of a hegemonic 'first world' feminism(s). ${ }^{6}$ My objective is not to equate the experiences of (so-called) 'third' and 'second world' women and feminisms, rather I want to emphasise how limiting constructions of 'second world women' represent assumptions about not only Soviet socialist gender politics, but even more presently, what it means for women in post-Soviet contexts to negotiate the legacies of state socialism.

Finally, this period marked a turn in how women poets expressed their relationship to, at once, their gender and their position as Ukrainians, and moreover, the extent to which the relationship between gender and nation has shaped contemporary feminist discourse in Ukraine. Literary scholars have often viewed the cultural surfacing during perestroika as a new wave of liberation for Soviet writers, particularly in Ukraine. Michael M. Naydan optimistically notes how it 'marked the opening of Pandora's Box in the process of the restoration and return of a truly free Ukrainian literary culture' (Naydan, 2006: 455). Hundorova, similarly, observes how perestroika literature

\footnotetext{
2 The terms perestroika and glasnost (perebudova and hlasnist in Ukrainian) are effectively constructed Russian words to signify the 'restructuring' and 'openness' (respectively) of a reimagined Soviet society, culture, and economy.

${ }^{3}$ This is not to say that there are no prior Ukrainian feminist thinkers or activists. On the contrary, there were many, including Lesya Ukrainka, Olha Kobylianska, and Milena Rudnytska (among many others), as historian Martha Bohachevsky-Chomiak has extensively documented.

${ }^{4}$ Recent work by scholars including David Chioni Moore, Vitaly Chernetsky, Dobrota A. Pucherová, and Róbert Gáfrik (among others) have drawn from postcolonial theory to examine the conditions of post-socialist and post-Soviet spaces, yet they have been clear that this application is not a superimposition of history. Postcolonial theory in this context, rather, seeks to consider dichotomies of power in order to produce a more robust and complex language for the legacies of empire in Eastern Europe-Russian, socialist, and Soviet.

5 The term 'second world woman' is not necessarily claimed or embraced by women in post-socialist contexts, as has sometimes been the case for so-called 'third world women.' I am, rather, using this term to indicate how Eastern European women's experiences have been framed and categorised in the West.

${ }^{6}$ Binary usage of the terms 'East' and 'West,' as well as the reliance on 'First,' 'Second,' and 'Third World' divisions, is historically problematic and requires further nuancing. In this context, I use this terminology as a way to conceptualise and critique the construction of gender in relation to the political and ideological constructions of 'worlds.' I am not advocating for reductive geopolitical divisions, but rather I am trying to undermine how these divisions have limited robust articulations of transnational feminist thought, particularly in Western academic contexts.
} 
seemed to be an integral part of the nation- and state-building process. Assuming their historic national mission, Ukrainian writers produced works that would satisfy not only aesthetic but also political, sociological, and cognitive needs (Hundorova, 2001: 251).

The tendency to see this decade as a promising cultural renaissance is indicative of the cultural landscape from which Soviet writers emerged: one that, prior to the $1980 \mathrm{~s},{ }^{7}$ remained under the grip of restrictive, and even deadly, censorship. The marked openness of this decade was accompanied by new ways of representing gendered and feminist concerns, and as such, I emphasise the ways in which women's poetic re-representation of Soviet life heralds a transition in Ukrainian feminist thought. In particular, I propose that this intellectual shift emerged from Soviet women's poetic expression of their vested interest(s) in national, ecological, and ethical concerns as tied to women's sexual and reproductive bodies. While the poetry examined here is not always overtly subversive in its treatment of women and gender, my interest lies in the extent to which perestroika yielded, for women, sharper and more vulnerable poetic articulations of their gendered subjectivities, including the performances of maternal, domestic, and national identities. As such, the peculiarities of gender cannot be excluded when examining Soviet literature of this period, and particularly for Ukrainian women, as these embodied concerns were also tied to a national interest, separate from Russia and other Soviet states. In so doing, more complex expressions of intimacy and belonging emerged-language that would become essential to Ukrainian feminism in the post-Soviet period of the 1990s (or the 'ninetiers').

\section{GENDER AND 'SECOND WORLD' DIFFERENCE}

Regarding the concepts of gender and women, and similarly, the representations of what it means to be 'masculine' or 'feminine,' 'male' or 'female,' and 'man' or 'woman,' it should be emphasised that these definitions vary considerably across cultures, histories, languages, and disciplines. For the purposes of my discussion, I draw from Susan Gal and Gail Kligman's definition of gender in their comparative-historical work in The Politics of Gender after Socialism:

[Gender is] the socially and culturally produced ideas about male-female difference, power, and inequality that structure the reproduction of these differences in the institutionalised practice of society (Gal and Kligman, 2000: 4).

Broadly speaking, I define contemporary feminism(s) to extend beyond women-identified subjectivities: it must acknowledge that the embodied and interconnected categories of gender, sexuality, and race are themselves knowledge systems produced through complex social and cultural structures. Feminist studies as a discipline, moreover, must develop theoretical tools and praxis that can mitigate domination and oppression. In the Eastern European context, I echo the work of Gal and Kligman (2000) as well as Maria Bucur (2008), Kristen Ghodsee (2018), and Francisca de Haan (2010) (among others), all of whom have stratified their treatments of these categories within a post-socialist context, acknowledging the ways in which patriarchal structures and institutions have differed from those in the West. This was due in part to the triangulated relationships between men, women, and the state, rather than women's established reliance on individual men. This is not to say Soviet society achieved the genderless utopia purported in many of its constitutional ideals. Gender remained a key organising principle throughout the Soviet Union, beginning immediately following the Revolution in 1917, as Sarah Ashwin (2000: 1) describes, the Soviet system produced its own form of patriarchy through the state's role as 'universal patriarch to which men and women were subject'. The Communist Party worked to 'transform traditional patterns of gender relations in order to consolidate its rule' as a way to undermine the 'social foundations of the old order' (Ashwin, 2000: 1). While legally women and men were considered equals, Soviet gender roles were nevertheless prescriptive, as, together, women and men were to build communism via their distinctive responsibilities. Women were idealised as 'worker-mothers,' expected to participate in the waged labour force, which gave them financial independence, but they were also to produce and raise the next generation of workers, and in return, the state provided support for their capacities as mothers. Men, on the other hand, Ashwin notes, had fewer responsibilities but more status, as they were able to work as soldiers, leaders, and managers, thus managing the communist system more directly (Ashwin, 2000: 1). To better reframe these divergent feminist and gender histories is to consider how this public/private division has often been interrogated in Western scholarship, particularly in terms of gendered divisions of labour, limiting women's participation in political and social arenas.

To understand a Soviet model of gender, one must consider that these expectations were structured primarily around social and political (as opposed to public and private) domains. In "The Gender of Resistance in

\footnotetext{
${ }^{7}$ This was even the case throughout the 1980s, as evident in Ukrainian poet Vasyl Stus' 1980 sentencing to a Soviet labour camp for 'anti-Soviet activity,' where he died in 1985.
}

(C) 2020 by Author/s 
Communist Poland," Padraic Kenney clarifies this difference by describing how, in communist societies, 'there is at best minimal space for public interaction or public opinion outside the state' (Kenney, 1999: 401). In twentieth century capitalist societies, he continues, the division exists symbolically 'between productive (breadwinning) and non-productive spheres' (Kenney, 1999: 401-402). Kenney, importantly, points to the embedded Western assumptions about feminist concerns in Eastern Europe, emerging from a mistranslation (or perhaps a superimposition) of the structures within which gender is performed. Building on Kenney, Bucur emphasises the significance of the 'fundamental genderedness of political and social life'-phenomena that must be considered when examining the histories of dissent and solidarity in communist societies (Bucur, 2008: 1388). For Soviet Ukrainian women, this political and social division was also significant. In some ways, women were able to move between these boundaries much more easily than men, accessing not only this 'social' space of domesticity, but also participating in the waged labour force. However, regardless of their access to productive spheres, women were still, in most cases, expected to maintain their auxiliary roles.

The relationship between feminism and nationalism has often been precarious, and some Western feminist scholarship has critiqued nationalism as a gendered, masculinist, often violent, project and thus incompatible with feminist ideals. In her discussion of the South African context, Ann McClintock posits that, 'all nationalisms are gendered, all are invented and all are dangerous' in the sense that they 'represent relations to political power and to the technologies of violence' (McClintock, 1991: 104-105). However, within the context of state socialism, the promotion of nationalism has often emerged from a different reality, particularly as it relates to women and women's interests, and it is here that I want to make a comparative distinction between some feminism(s) in the West and those in Ukraine. In terms of pre-perestroike feminist thought, the development of women's movements in Ukraine throughout the twentieth century worked to address Soviet women's lives, but at the same time, they were closely tied to the idea of 'Ukrainianness' and Ukrainian interests. Martha Bohachevsky-Chomiak describes how the organisation the World Union of Ukrainian Women, developed in 1934,

sought to defend the rights of Ukrainian women and work toward the expansion of those rights. The political situation, however, required stress upon the adjective Ukrainian rather than the noun women (Bohachevsky-Chomiak, 1988: 280).

Oksana Kis, for example, refers to this as 'national feminism,' which she describes as 'a unique movement beyond existing feminist paradigms' and one that 'explores women's contributions to a Ukrainian national cause' (Kis, 2012: 154). The legacy of this vested interest in Ukrainianness has been significant in terms of how feminist thought in Ukraine has emerged alongside, and even enmeshed in, the development of populist and nationalist rhetoric.

Not unlike many of the discourses around 'third world' feminisms, academic research on 'second world' feminism(s) is often hampered by its reliance on the ideological and theoretical tools of hegemonic 'first world' or 'Western' feminism(s). Mohanty's description of the construction of the 'third world woman' identifies her as a 'singular monolithic subject' who appears throughout Western feminist texts (Mohanty, 1997: 51). The problem of singularity, for her, is an analytic one: it constructs women of 'third world' as a monolith, and it is within this production of 'third world difference' that oppression, and thereby colonisation, occur (Mohanty, 1997: 53-54). Likewise, a similar (yet, and importantly, not equal) monolithic construction is evident in the production of the 'second world woman.' The development of 'second world' feminism(s) — perhaps more aptly referred to as postsocialist or post-Soviet feminism(s) - becomes legible to a Western audience through a reliance on 'difference.' In other words, the trajectories of feminist thought and praxis in a Soviet/post-Soviet context (and socialist/postsocialist contexts more broadly) are often, and problematically, evaluated in relation to the 'first.' 8 'The emphasis placed on the relationship between 'worlds,' however, provides a limited, narrow vision of not only the

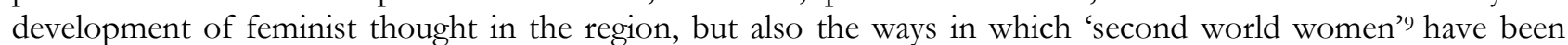
viewed in opposition to those of both the 'first' and the 'third.' Kristen Ghodsee describes some of the stereotypes perpetuated by Western feminists who saw state socialist women as 'blind dupes of Marxist patriarchy' and thus 'insufficiently concerned with women's true issues.' She cites, specifically, Barbara Wolfe Jancar (1978) and Nanette Funk (1993), both of whom reject the possibility of feminist thought in the Eastern Bloc, as Funk writes, '[communist women's organisations] were not agents of their actions, proactive, but instruments' of a patriarchal state,' calling recent research on state socialist women's organizations 'feminist revisionist' (Ghodsee, 2018: 14). In

\footnotetext{
${ }^{8}$ It is important to emphasise, as Mohanty does in her later work, the extent to which these demarcations are unable to represent the complexity of peoples and ideas within and between 'worlds,' as non-monolithic cultural and political spaces. I want to consider how such artificial distinctions themselves produce flattened assumptions about the subjectivities that inhabit them.

${ }^{9}$ I want to be cautious here so as to not imply that the so-called 'second world' is itself a monolithic unity. It is vital to note that the practices and realities of state socialism were varied throughout the Eastern Bloc. The very idea of 'worlding' itself already undermines the spectrum of lived experience in all three contexts.
} 
her Introduction to the Aspasia forum, "Ten Years After: Communism and Feminism Revisited," Francesca de Haan (2016) points out that one of the problems with this view is the assumption that there is a correct interpretation of the history of state socialist women's organisations. Krassimira Daskalova (2016) highlights the assumptions about epistemological hegemony, asking 'who is entitled to provide "THE definition" of feminism/s,' and similarly, Magdalena Grabowska (2016) challenges the 'universalizing representation of liberal Western feminism.... as the sole point of reference for the marginal East European women's movement' (qtd. in De Haan, 2016: 104). While I do not extensively examine Soviet or other communist women's organisations, I include this discussion in order to emphasise the ways in which some Western feminist discourses have, intentionally or not, relied on Cold War assumptions in their framing of communist women's experiences, rendering them incompatible with feminist thought.

In my consideration of Ukrainian women's poetry, I want to give attention to the ways in which the 'East' and 'West' both produce and have been produced by particular ways of knowing, yet these embedded epistemologies neither exist in vacuums nor do they yield a singular experience. Moreover, the production and performance of gender, as its own body of knowledge and way of knowing, participates in this negotiation with modernity through both resistance and accommodation. In the case of late Soviet Ukraine, and especially during perestroika, women continually confronted new ways of not only being 'modern,' but also reinterpreting their subjectivity to the state, in both bodily and psychological terms. However, and importantly, I am not arguing that the 'first world' is responsible for this shift, nor do I centralise Western feminism(s) as more progressive than those of the 'second' or 'third.' What this indicates, rather, is the significance of where societal fractures have occurred, and moreover, how they have been mediated through discourses of democratisation and liberalisation. The monolith of a 'second world woman,' then, emerges in the Western imaginary as an embodiment of this fracturing, formed through a reliance on the theoretical tools of hegemonic, 'first world' feminism. By giving close attention to some of the poetic contributions of Ukrainian women writers in the final Soviet years, what emerges is a nuanced and multidimensional vision of gender in a 'second world' context: one that challenges the flattening of feminism as something that only emerged as a result of democratisation post-1991. Moreover, it exposes the ways in which life under communism during this period both shaped and was shaped by women's representations of their gendered subjectivity. To do so, I focus specifically on how women poets of perestroika initiated new ways of speaking and representing gendered divisions of Soviet subjectivity on the cusp of transition. ${ }^{10}$ In this sense, the works of Zhylenko, Bilotserkivets, and Zabuzhko are key: it is through their shared, yet differing, expressions of an embodied experience of gender in the period just prior to transition that a complicated representation of gender in the so-called 'second world' emerges.

\section{TRANSGRESSIVE BODIES: UKRAINIAN WOMEN POETS OF PERESTROIKA}

In the final decade of the Soviet Union, many writers took up more radical rejections of a prescriptive Soviet ideology, or what Hundorova describes as 'providing an alternative to the Soviet literary paradigm' (Hundorova, 2001: 259). Larissa M. L. Z. Onyshkevych comments on how Ukrainian poetry shifted from the 1960 s to the 1980s, as she observes:

Poets of the 1960s were often concerned with intellectual, artistic, and ethical issues, in the 1980s, ethical concerns and ecology (both biological and cultural) predominated (Onyshkevych, 1993: 365).

This turn was due primarily to the Chornobyl disaster, but also 'the fate of future generations, and the Ukrainian culture (often symbolised by Ukrainian language itself)' moved to the forefront (Onyshkevych, 1993: 365). In a large sense, these changes were also in concert with loosening censorship, but I would add to Onyshkevych's assessment by drawing attention to the gendered component of these shifts, including how women's sexual and reproductive bodies were especially vulnerable to increasing national and ecological anxieties during this period. To do this, I will, in the following, provide close analyses of selected poems from Zhylenko, Bilotserkivets, and Zabuzhko during perestroika. While these examples demonstrate poetic subversion in a specifically late Soviet Ukrainian context, I want to emphasise that they also speak to broader concerns regarding gendered subjectivity in state socialist contexts, particularly in terms of how women have used the language of embodiment to interrogate the boundaries between 'womanness' 11 and nation as they relate to the politics of intimacy and belonging.

Beginning her work during the Soviet Thaw era of the early 1960s, Iryna Zhylenko was part of Ukraine's 'sixtiers' ('shistdesyatnyky') generation of poets. This early period secured the creativity and community essential to establishing a critical cultural movement, and one that, in many ways, forged new ways of thinking about what it

${ }^{10}$ To be clear: of the three women poets examined, only Zabuzhko referred to herself as 'feminist,' at least during this period.

${ }^{11}$ By 'womanness' I am referring to an embodied performance of the social category of 'woman.'

(C) 2020 by Author/s 
means to be not only Soviet, but also Ukrainian. Such new epistemological outlets, in many ways, paved the way for Ukrainian writers in the final decades of the Soviet Union, and particularly the writing that emerged with the eightiers during perestroika, including Bilotserkivets and Zabuzhko. In "Sertse" ("Heart"), 12 from her 1985 collection Ostannij vulychnyj sharmanshchyk (The Last Street Organ-Grinder), self-reflective, embodied language becomes visible, as she expresses, 'I am whole - a whole heart. The body is the world' (1). Not only does she connect her embodied experience as being part of the world, she also ascribes symbolic violence to that experience:

But the heart must fight, woman.

I fight until the elbows are warm in blood

and bruises boil over the knees. (2-4)

For Zhylenko, violence against the body is at once a barometer for her own gendered experience as well as that of the world. The female speaker, the heart, is indelible from the 'body' of the world — one in which she must fight to be in. This language of embodied struggle marks a contrast from Zhylenko's earlier work, which, while often challenged state-imposed literary expectations (mainly Soviet realism), did not offer such an explicit representation of the struggle she associates with 'womanness.' As such, I associate Zhylenko's overt feminist tone with the more lenient censorship that accompanied perestroika and glasnost: changes that ultimately did not correct the Soviet state's failures yet made room for more transgressive articulations of gendered subjectivity.

As Zabuzhko emerged during perestroika, her early work clearly engages a transgressive literary paradigm—and does so even more explicitly than Zhylenko's writing of the same period. Vitaly Chernetsky describes the arc of her work in contemporary Ukraine as producing a

testimony of survival and resistance as a writing woman in a postcolonial cultural dynamic and a critique of the intellectual and cultural legacies of conceptualising the oppressed nation (Chernetsky, 2007: 255).

In a 2019 interview, she self-identifies as 'the living result of underground education-classrooms of hometaught children the Ukrainian intellectuals organised in Kyiv in the 1960s' (Euromaidan Press, 2019). Her attentiveness to embodiment hints toward what would, in her post-Soviet writing, become a clearer engagement with the intersections of gender and the project of nation-building. This connection is evident in her 1989 poem, "Vyznachennya poeziyi" ("A Definition of Poetry"), ${ }^{13}$ wherein she begins:

I know I will die a difficult death -

Like anyone who loves the precise music of her own body,

Who knows how to force it through the gaps in fear

As through the needle's eye, (1-4)

By associating the awareness of her love for her body with not merely her mortality, but the prospect of 'a difficult death,' Zabuzhko attunes the reader to the correlation between violence and inhabiting 'womanness.' This quality is, in other words, inherently uninhabitable, particularly for those who are attune to the pleasures and desires of their own embodiment, as she continues by hinting at the erotic:

Who dances a lifetime with the body - every move

Of shoulders, back, and thighs

Shimmering with mystery, like a Sanskrit word,

Muscles playing under the skin

Like fish in a nocturnal pool. (5-9)

Zabuzhko's description of shimmering and mysterious 'shoulders, back, and thighs' highlights the materiality of her body. Moreover, by intimating the erotic through her somatic imagery, she moves towards a more subversive poetic construction, one that has not, prior to the 1980s, been especially visible in literature, and which becomes more pronounced in her post-Soviet writing. ${ }^{14}$ Halyna Koscharsky asserts that both Zabuzhko and Bilotserkivets reflect 'the development of a feminist worldview, at least from the viewpoint of urban Ukrainian women.' Moreover, she characterises the 1980s as the period when eroticism becomes characteristic of Zabuzhko's poetry and particularly in her treatment of Ukrainian history (Koscharsky, 2003: 312-313). Moreover, Zabuzhko's use of

\footnotetext{
12 Translation my own.

${ }^{13}$ Translated by Michael M. Naydan in From Three Worlds (1996).

${ }^{14}$ Beginning with Zabuzhko's Pol'ovi doslidzhennya z ukrayins'koho seksu (Fieldwork in Ukrainian Sex) in 1996, as well as her 1999 short story "Divchatka" ("Girls"), which includes a sapphic relationship between two young women.
} 
the erotic in writing about Ukrainian national history marks a significant turn in Soviet women's writing, evidenced by its resonance among Ukrainian women. Moreover, it challenges the assumptions made by Western feminists like Funk and Jancar, demonstrating that Soviet Ukrainian women were not merely 'blind dupes,' but rather were associating their own national history with representations of women's sexualised, often violated, bodies. The poetic, for Zabuzhko, is not merely a representation but an embodied project, reliant on and proliferated by her ability to bring precise awareness to her experience of 'womanness' - a boundary 'between two worlds,' as she reflects later in the poem:

And draw the soul up, trembling like a sheet of paper -

My young soul -

The color of wet grass -

To freedom - then

"Stop!" it screams, escaping,

On the dazzling borderline

Between two worlds - (28-34)

Visible here is Zabuzhko's movement toward a poetics that engages not only embodiment, but also identifies the liminality between 'worlds'-interpretable as both a poetic and ideological boundary—and with it, the possibility of transversing this liminality.

A poet, translator, and editor, Bilotserkivets began publishing her poetry in the late 1970s, just before Zabuzhko, and was influenced by Russian acmeism and French symbolism. Her work, likewise, offers a clarity and imagination that translates smoothly into English. Life and death thematically emerge throughout Bilotserkivets' poetry, and perhaps most notably in "We'll Not Die in Paris,"15 from her 1989 collection Lystopad (November). The title responds to the line 'I will die in Paris on Thursday evening,' from Peruvian poet, Cesar Vallejo's poem, "Black Stone on a White Stone" ("Piedra negra sobre una piedra blanca")—a line she includes as an epigraph. Bilotserkivets' poem itself reads like a eulogy, both as a meditation on death and grief, and also as a way of thinking about the idea of Europe through the prism of her 'Ukrainianness,' which she frames as provincial, separate from the presumed decadence of Western Europe. Her speaker begins by describing her subject's death:

You forget the lines smells colors and sounds

sight weakens hearing fades simple pleasures pass

you lift your face and hands toward your soul

but to high and unreachable summits it soars

what remains is only the depot the last stop

the gray foam of goodbyes lathers and swells

already it washes over my naked palms

its awful sweet warmth seeps into my mouth

love alone remains though better off gone (1-9)

Bilotserkivets' speaker emphasises not so much the subject's memory, but instead, what has been forgotten, as she engages with the certainty of death. In so doing, she represents this process as a loss or separation from what is familiar: lines, colours, sounds, and sights. Such objects are, importantly, received and experienced through the body - a location that is, for her, vulnerable and provisional, yet sexual and eroticised, as she differentiates between the temporariness of her body and something more timeless. What remains with the subject's body is the love of others ('the gray foam of goodbyes'), manifested through the experience of grief.

For Bilotserkivets, the connections among loss, grief, and the geopolitical divide between 'West' and 'East' are intimately tied to her awareness of what it means for her to be Ukrainian, particularly during this period. The seismic ideological and political changes are reflected through her engagement with the question of belonging, which she represents through her creation of this distinctive space wherein the loss occurs:

in a provincial bed I cried till exhausted

through the window a scraggly rose-colored lilac spied

the train moved on spent lovers stared

at the dirty shelf heaving beneath your flesh

outside a depot's spring passed quiet grew (10-14)

15 Translated by Dzvinia Orlowsky in From Three Worlds (1996). The original Ukrainian poem does not include a title, but rather begins with Vallejo's line, 'Ya pomru v Paryzhi v chetver uvecheri.'

(C) 2020 by Author/s 
Outside of this space is movement and change: a train rushes by, and spring, a period often representing rebirth and renewal, passes, leaving death inside. Bilotserkivets again uses the language of eroticism ('spent lovers,' 'heaving beneath your flesh') to articulate a sense of belonging. The idea of 'national belonging,' in other words, is explored through the erotic. Like Zabuzhko, she uses the erotic to consider her own positionality in the so-called 'second world'-highlighting her awareness of her perceived provincialism - not only how she sees herself, but how she believes she is seen by others. Moreover, the speaker's world remains separate, lodged somewhere between this movement and stasis, life and death. In the poem's titular stanza, she asserts:

we'll not die in Paris I know now for sure

but in a sweat and tear-stained provincial bed

no one will serve us our cognac I know

we won't be saved by kisses

under the Pont Mirabeau murky circles won't fade (15-19)

Here, Maria G. Rewakowicz reads her tone, along with much of the poetry of this period, as pessimistic, suggesting that Bilotserkivets expresses,

her generation's despair over the long-kept divide with regard to the Western cultural heritage and over the provincialism imposed by the Soviet authorities, as well as a deep, implicit longing to be culturally part of Europe (Rewakowicz, 2009: 289).

Similarly, Halyna Koscharsky assesses the poem's cynicism, asserting how the lines 'we'll not die in Paris I know now for sure/but in a sweat and tear-stained provincial bed' became a kind of 'calling card of the generation' of underground poets (Koscharsky, 2003: 312). Her speaker's observation and assertion reflect some of the uncertainty that accompanied Ukrainian poets (and East European poets more broadly) at this time, as they wrote between the boundaries of knowing and unknowing.

Bilotserkivets, in a sense, responds to some of the concerns about prioritising 'Ukrainianness' addressed by early Soviet Ukrainian women's movements; however, rather than praising this quality, she undermines it. She, in other words, responds to the question of 'Europe'- who can and cannot belong - and concluding that she cannot, and, unlike her foremothers, grieves that absence. However, the idea of 'Europeanness,' which she represents through the imaginary of Paris, becomes a kind of caricature, presumably filled with romance, cognac, and beautiful architecture, all of which is juxtaposed by her 'provincial bed.' Her observation relies on this European imaginary, bolstered by assumptions about what Europe is and is not, what it can and cannot provide, and the extent to which the fantasy of Western Europe is a marker of prosperity. Even presently, such thinking has played into the imaginary of Ukraine's future, serving as a barometer for not only its national progress, but also in measuring the success of its liberalisation. This is not to say there were (and are) not real disparities poets like Bilotserkivets were responding to, however, it is the way in which the image of Europeanness exists as a perceived end. It relies on an oversimplified (and often problematic) East/West binary, one that associates progress with the 'West' and backwardness with the 'East.' The self-consciousness of the 'East/West' imaginary also played a role in Zhylenko, Bilotserkivets, and Zabuzhko's responses to Chornobyl—all of which, in some way, confront an uncertain future through their representations of the embodiment. The body (through both its absence and presence) intervenes in the poets' recognition of how, and to what extent, their national territory was affected, ushering in complex expressions of embodiment and environment.

\section{GENDER AND THE POETICS OF DISASTER: WRITING CHORNOBYL}

The enormity of the Chornobyl catastrophe in April of 1986 was, arguably, one of the major catalysts for the dissolution of the USSR in 1991. The subsequent denial and dangerous mishandling on the part of Soviet authorities contributed to a rapid decline in citizens' faith in the promise of a communist utopia. As the disaster occurred in the midst of glasnost reforms, put into effect several months before, the event was something of a litmus test for the system's credibility. Due to the severity of this event, and amid the perestroika and glasnost reforms, as the consequences slowly came to light for the public, so too did the literary responses reflect a shared anxiety regarding its ecological and political repercussions. As Zhylenko, Bilotserkivets, and Zabuzhko were actively writing and publishing during this time, it is no surprise that all three poets responded to disaster in the late 1980s. Their Chornobyl poetry even became part of a poetic theatre performance entitled "Explosions," written and directed by translators Virlana Tkacz and Wanda Phipps, and performed in New York City in November of 1991 (Tkacz, 2006). Most significantly, their poems reflect the disaster's impact on everyday life, both inside and outside of the exclusion zone, considering especially its effect on women and children. 
The literary response to Chornobyl reflects how gender is represented and instrumentalised through catastrophe, yet scholarship on Chornobyl poetry has frequently overlooked this gendered component (at least in English-language scholarship). Moreover, the precarity and danger of the event and its aftermath, particularly through its environmental and somatic impact, is itself a feminist issue. In "Re-Writing Corporate Environmentalism: Ecofeminism, Corporality, and the Language of Feeling," Mary Phillips explores what she calls 'creative subversion and re-imagining of corporate environmentalism through a poetic writing of nature and bodily embeddedness in the natural world' (Phillips, 2014: 443). Citing Hélène Cixous (1976, 1981), she considers 'ways to re-imagine looming ecological crises as being intertwined with our corporeal existence' and thus we 'feel moved to respond' (Phillips, 2014: 449). Writing from (and about) the body, Cixous argues, can 'disrupt binary thinking' and 'explode phallocentrism,' and women's writing (she calls this 'the feminine text') offers the possibility of disruption because it 'writes of and from the body' and 'is thus subversive and volcanic' (Phillips, 2014: 451). While I want to avoid essentialising 'women's writing,' Cixous' premise is useful for considering how the representation of the body has responded to, and even mitigated, ecological crises. Women's reckoning with the physical, environmental, and even reproductive costs of its consequences contributed to a broader reimagining of positionality within and value to the state. In this sense, the disaster itself, along with the literary responses to it, presented a turning point in how Soviet Ukrainian women imagined themselves, and their bodies, in both national and ecological contexts.

Visible in Zhylenko, Bilotserkivets, and Zabuzhko's Chornobyl poetry is the ways in which they each construct an image of domestic space (inhabited, imagined, or vacant), using it to locate and articulate where the human cost of the disaster lies. In Zhylenko's poem "V Xati" ("In the Country House," 1990 ), ${ }^{16}$ she depicts an interaction between a mother and son in the wake of the explosion. She begins by identifying the ways in which, even amidst ecological devastation, her performance of 'womanness' remains intact:

Now back to the chores. Rake out the ashes.

Start the fire. Sweep away the cobwebs...

And cook some potatoes for dinner.

Dead or alive - I'm still the housekeeper.

Dead or alive - I'm still the mother.

I come out of a deep dark depression,

to feed my little son

to tell him a fairy tale about happiness.

... Joy fills my lungs -

as my son offers me a chrysanthemum through the window. (1-10)

By her tone, it is unclear as to whether or not she critiques the speaker's insistence on her domestic roles as mother and homemaker. Yet her awareness of a persisting expectation for this gendered performance of caretaking is readable. This embodied act of 'womanness' (or what is designated as 'womanness') is manifested through her role as 'housekeeper' and 'mother,' and in so doing, she preserves a status-quo, one that is, seemingly, crucial for survival. Zhylenko's speaker then addressees the 'doses of radiation' that she continues to be psychically aware of and burdened by. She describes this anxiety though her interaction with the son:

But a raven's voice is already counting out the dose of radiation.

"Wash your hands, wash your hands, my son..."

"Mom, a kitten. How sweet.

You're such a poor little dirty stray..."

The clock starts to beat out the doses of radiation:

Wash your hands! Wash your hands! Wash your hands!

"Mom, please let me go play in the sand.

The kids are burying the reactor.

Don't worry - it's just a hunk of metal.

Granddad caught some crayfish

And treated me to some. They were great.

Why is everything we eat canned, canned, canned? (11-22)

16 Translated by Virlana Tkacz and Wanda Phipps for the Brama website. 
The speaker's fears are located in the natural world — in the mundane objects of everyday life that have suddenly become dangerous: the cat her son touches, the sand he wants to play in, the fish and mushrooms fed to him. As a response, she concludes the poem by embodying, and thus taking on, the radiation itself:

My heart beats out the doses of radiation

On every grain of sand,

On every little weed.... (33-35)

Zhylenko draws an intimate connection between the speaker's body, particularly the internal and external labour of her body, and nuclear disaster-both spaces of production, reliant on particular forms of care and sustenance. Her physical reflection of this trauma speaks to Phillips' discussion of maternal bodies in ecofeminism, noting how the 'boundaries of [women's] embodiment' (menstruation, birth, lactation) tend to be 'fluid and insecure' and thus regarded as inferior. Likewise, she calls for further exploration of the possibilities of women's 'embodied experiences of nature' to consider the representation of 'emotion, love and care' (Phillips, 2014: 446-447). For Zhylenko, even while acknowledging ecological catastrophe, she uses embodied, maternal images to interrogate the connection between woman and nation, and particularly a nation in crisis: she seemingly cannot help but take on its trauma physically.

In "Pryp'yat - Natyurmort" ("Prypiat-Still Life," 1990), ${ }^{17}$ Zabuzhko does not distinctly represent any gendered aspect of Chornobyl. Her poem, rather, constructs and observes a space in which human absence itself becomes a subject. Through language, she excavates the affected space of Prypiat as a way of imagining the unimaginable (both to Soviet citizens as well as the international community). She begins:

It could be dawn.

The light crumpled like sheets.

The ashtray full.

A shadow multiplies on four walls.

The room is empty. (1-5)

It is through Zabuzhko's use of the contingent 'could' ('zdayetsya'), which can also be translated as 'seems to be', that she reflects the phenomenon of unknowing in the years following the disaster. In so doing, her speaker constructs her own knowledge of the event, identifying and observing Chornobyl's human and ecological cost. Zabuzhko's speaker, rather than speaking of embodiment directly, eulogises the absent body: an image that is in many ways more powerful:

No witnesses.

But someone was here.

A moment ago twin tears shimmered

On a polished wood.

(Did a couple live here?)

In the armchair a suit, recently filled by a body,

Has collapsed into a bolt of fabric. (6-12)

Significantly, for Zabuzhko, the speaker's focus is on the space of a home: the lived-in, domestic, private world of the social, closely tied to images of maternity and 'womanness.' She is not directly addressing, in other words, the failures of the state, nor does she give a face to real villains or victims, as there are 'no witnesses' ('zhodnoho svidka'). Here, the tragedy lies in citizens' dislocation from spaces of belonging-moving from the known and familiar, to the unknown and unfamiliar. Moreover, she acknowledges the state's violation of this intimacy, which she conveys through the absence of her subjects' bodies. In a sense, the speaker herself is also disembodied, as by illuminating this absence she is an observer, rather than a victim, of the tragedy. Yet the absence, for Zabuzhko, signals something more insidious--the freshness of the disaster itself, the immediacy of loss, and the inadequacy of the state's response, as the speaker invites the reader:

Come in, look around, no one's here

Just the breathing air, crushed

As though by a tank.

A half-finished sweater remembers someone's fingers.

${ }^{17}$ Translated by Lisa Sapinkopf in A Kingdom of Fallen Statues (1996). 
A book lies open, marked by a fingernail.

(How amazing, this silence beyond the boundary!) (13-18)

Again, Zabuzhko returns to the boundary - a metaphor for not only the unpredictability of a post-Chornobyl Ukraine, but also her awareness of a Soviet liminality - a country that would abruptly end and, like the victims of Prypiat, would find themselves reckoning with its absence. Poetry disrupts this absence by acknowledging such 'in-betweenness,' and in this way, the recreation of a place that has been lost reflects her feminist consciousness. It is through her parsing of in-betweenness, especially with the boundary of the body, that Zabuzhko build a language for her feminism.

The longest of the three Chornobyl poems, Bilotserkivets' "Traven" ("May," 1987) ${ }^{18}$ is divided into five parts, incorporating dense imagery and description, along with second person voice, to orient the reader in the experience of a child following the disaster. Like Zhylenko, Bilotserkivets thematically turns to images of children and childhood, a device Hundorova argues, in Ukrainian literature of the 90s, 'reflects the condition of a new cultural consciousness that has arisen from the wreckage of post-Soviet Ukraine' (Hundorova, 2001: 268). However, this device can also be seen slightly earlier, as poets of Ukraine's last Soviet generation are, in many ways, preparing for a 'new world' through their representation of uncertainty through the vulnerability of children. Her speaker opens by invoking a vague memory of childhood:

A soft sob at midnight. Still asleep you can't remember where, in what corner

of the suddenly empty room.

Was it there, where your bed stood when you were a child?

Where the shadows of tiny breasts first

appeared over the ribs_-during childhood, cooing dark skeins of trembling

syllables, fears and cries?...

You were born

far away from an airport or even a railroad! (1-10)

Like Zabuzhko, the speaker in Bilotserkivets' poem brings her reader into an imagined space-one in which the subject's memory is uncertain and that has suddenly become empty. It is, moreover, clear from these first few lines that the poem's subject is a woman, as the speaker mentions 'the shadows of tiny breasts' appearing during her childhood - a statement that indicates her formative relationship to the space described. Her speaker continues, returning the reader to this place of simultaneous memory and uncertainty:

You wake again, and again you're in the building where you lived

with your parents when you were small, but today

strangers live there, and they've let

both of you spend the night in your old room, and even

served you tea- a different kind, in a different cup,

not the white one with blue dots—and your lips

find traces of someone else's tentative sips

who

drank from my cup? (11-19)

For Bilotserkivets, there is a clear 'before' and 'after' Chornobyl, treated as two separate lives: the primitive, as marked by a childhood, and the modern, marked by the machinery of the 'new century':

warm memories, of milk, of tears

of mother's kindness, of laughter, and of the sound

of bare feet in the garden

you were born

before nuclear power plants or dead rivers,

or trains crammed with children-what straws

will they grasp in the new century?... (24-30)

${ }^{18}$ Translated by Virlana Tkacz and Wanda Phipps in AGNI (1991).

(C) 2020 by Author/s

$11 / 14$ 
Bilotserkivets continues later in the poem by meditating on the human cost of Chornobyl:

others

put out the flames

in the reactor's burning heart;

we, dressed in white lab coats and dosimeters in our hands;

in military epaulets, in soldiers' uniforms;

young pregnant women and girls

with children that will never be born

victims and rescuers in the burning heart of Europe. (47-54)

The emphasis on compromised reproduction and motherhood, visible especially in Zhylenko and Bilotserkivets' poems, again, demonstrate the ways in which women's writing reflects not only the somatic burdens of the disaster, but the extent to which this endangers a national future. All three poets center the uncertainty of a post-Chornobyl future as itself a subject in their poems, and likewise, all three utilise the image of women's bodies, either their presence, compromised by the radiation, or their absence, removed from a space of belonging as the result of the disaster. In this regard, a perceptible shift emerges in Soviet Ukrainian women's writing during this period-one that is more willing to articulate indignation for what they have lost or been denied, ushering in a clearer, more subversive feminist language that would continue in the coming decade.

\section{CONCLUSION: WRITING BETWEEN THE BOUNDARIES}

\section{To return to Zabuzhko's 1995 essay, she concludes by reflecting on a newly independent Ukraine:}

Thank God the nation does exist, its development is guaranteed by newly born statehood, so we are not forced any longer to bear the exclusive responsibility for its historical fate, to be national heroes, and redeemers, or we don't pretend to be (Zabuzhko, 1995: 275).

Zabuzhko was not alone in associating poets with messianic (and even martyological) figures for Soviet Ukraine, and her sense of relief that accompanied independence is indicative of how she saw her role as a Soviet poet-inevitably tied to the nation, intentionally or not. For Soviet Ukrainian women poets especially, so too were their representations of 'womanness' and embodiment tied to a sense of national responsibility. As the USSR quickly moved towards collapse in the late 1980s, so too did Soviet writing reflect the anxieties of belonging, identity, and futurity. While there remained some hope in the Soviet system through the potential of perestroika and glasnost reforms, this was offset by visibility of the Soviet authorities' dishonesty in its final years, particularly with Chornobyl. As Ukraine moved rapidly toward independence, ${ }^{19}$ women writers especially sought to represent the gendering of national and ideological spaces, and likewise to reckon with the impact of what Catherine Baker calls 'the micropolitics of intimacy and sexuality' of what would become a 'new' Ukraine (Baker, 2017: 2). By examining the development of a Ukrainian feminist discourse through the poetic, what surfaces most clearly are Zhylenko, Bilotserkivets, and Zabuzhko's articulations of in-betweenness, doing so through a shared awareness of their own bodies, and likewise, the political and social expectations for their performance of gender.

Although they emerged with different generations, Zhylenko, Zabuzhko, and Bilotserkivets' poetry during perestroika coincides through their respective representations of how the anxieties of performing 'womanness' participated in the re-vision of 'Ukrainianness.' More visible and disruptive feminist literature has emerged in more recent years and has been discussed more extensively in scholarship; my focus on perestroika intervenes by exploring how Ukrainian women poet's representations of embodiment often reflected of their relationships to a shifting national idea. In so doing, they fostered more subversive articulations of their gendered subjectivity. This subversion became especially sharp in their responses to Chornobyl, as all three poets recognised the impact it had, and would continue to have, on the nation's future and security. In other words, their poetic consideration (and even critiques) of the nation in a moment prior to transition is not exclusive from or incompatible with Ukrainian feminism; it is, rather, a vital moment in its genealogy. Likewise, as I have demonstrated, this is often performed by giving attention to their vulnerabilities within these gendered spheres of belonging, including their domestic, maternal, sexual, Soviet, and Ukrainian identities.

\footnotetext{
${ }^{19}$ Importantly, that the idea of Ukrainian independence was not necessarily at the forefront of citizens' minds during perestroika, as many still clung to the idea of Sovietness. As ethnographer Alexi Yurchak emphasises, the 'system's collapse had been profoundly unexpected and unimaginable to many Soviet people until it happened' (Yurchak, 2006: 4). I do not see the examined poets as explicitly writing about independence, but rather responding to a rapidly changing political environment.
} 


\section{REFERENCES}

Ashwin, S. (2000). Introduction, in S. Ashwin (ed), Gender, State and Society in Soviet and Post-Soviet Russia (pp. 1-29). London: Routledge.

Baker, C. (2017). Introduction, in C. Baker (ed), Gender in Twentieth-Century Eastern Europe and the USSR (pp. 1-22). London: Palgrave Macmillan.

Bilotserkivets, N. (1991). "May." translated by Virlana Tkacz and Wanda Phipps, AGNI 34, 51-54.

Bilotserkivets, N. (1996). "We'll Not Die in Paris." in E. Hogan (ed), From Three Worlds: New writing from Ukraine (pp. 148-151). Boston: Zephyr Press.

Bilotserkivets, N. (1989). Lystopad [November]. Kyiv: Rad. Pys'mennyk.

Bohachevsky-Chomiak, M. (1988). Feminists Despite Themselves: Women in Ukrainian community life 1884-1939. Edmonton: Canadian Institute of Ukrainian Studies.

Bucur, M. (2008). An archipelago of stories: Gender history in Eastern Europe. The American Historical Review, 113(5), 1375-1389.

Chernetsky, V. (2007). Mapping Postcommunist Cultures: Russia and Ukraine in the context of globalization. Montreal: McGill-Queen's University Press.

De Haan, F. (2010). Continuing cold war paradigms in western historiography of transnational women's organisations: The case of the Women's International Democratic Federation (WIDF). Women's History Review, 19(4), 547-573.

De Haan. F. (2016). Introduction, in F. De Haan (eds), Ten years after: Communism and feminism revisited. Aspasia, 10, 102-111.

Euromaidan Press (2019). Oksana Zabuzhko: Ukraine is at the forefront of a huge world battle that will transform humanity. Available at: http://euromaidanpress.com/2019/03/27/oksana-zabuzhko-ukraine-is-at-theforefront-of-a-huge-world-battle-that-will-transform-humanity/. (Accessed 8 May 2020).

Gal, S. and G. Kligman. (2000). The Politics of Gender after Socialism: A comparative-historical essay. Princeton: Princeton University Press.

Ghodsee, K. (2018). Second World, Second Sex: Socialist women's activism and global solidarity during the Cold War. Durham: Duke University Press.

Hundorova, T. (2001). The canon reversed: New Ukrainian literature of the 1990s. Journal of Ukrainian Studies, 26(12), 249-270.

Hundorova, T. (2019). The Post-Chornobyl Library: Ukrainian postmodernism of the 1990s. S. Yakovenko (trans.). Boston: Academic Studies Press.

Kenney, P. (1999). The gender of resistance in communist Poland. The American Historical Review, 104(2), 399-425.

Kis, O. (2012). (Re)constructing Ukrainian women's history, in O. Hankivsky and A. Salnykova (eds), Gender, Politics, and Society in Ukraine (pp. 152-179). Toronto: University of Toronto Press.

Koscharsky, H. (2003). Ukrainian feminist poetry: Is it coming of age?, Canadian Slavonic Papers/Revue Canadienne des Slavistes, 45(3-4), 307-316.

McClintock, A. (1991). No longer a future heaven: Women and nationalism in South Africa. Transition, 51, 104123.

Mohanty, C. T. (1997). Under western eyes: Feminist scholarship and colonial discourse, in A. McClintock, A. Mufti, and E. Shohat (eds), Dangerous Liaisons: Gender, nation, and postcolonial perspectives (pp. 255-277). Minneapolis: University of Minnesota Press.

Naydan, M. M. (2006). Ukrainian avant-garde poetry today: Bu-Ba-Bu and others. Contemporary Ukrainian Literature and National Identity, special forum issue of The Slavic and East European Journal, 50(3), 452-468.

Onyshkevych, L. M. L. Z. (1990). Echoes of Chornobyl in soviet Ukrainian literature. Agni, 29/30, 279-291.

Onyshkevych, L. M. L. Z. (1993). Ukrainian literature in the 1980s, in W. M. Cummins (ed), Shifting Borders: East European poetries of the eighties (pp. 363-400), Cranbury, NJ: Fairleigh Dickinson University Press.

Pavlychko, S. (1992). Between feminism and nationalism: New women's groups in the Ukraine, in M. Buckley (ed), Perestroika and Soviet Women (pp. 82-96). Oxford: Cambridge University Press.

Phillips, M. (2014). Re-writing corporate environmentalism: Ecofeminism, corporeality and the language of feeling. Gender, Work and Organization, 21(5), 441-458.

Rubchak. M. J. (2001). In search of a model: Evolution of a feminist consciousness in Ukraine and Russia. The European Journal of Women's Studies, 8(2), 149-160.

Rewakowicz, M. G. (2009). Women's literary discourse and national identity in post-soviet Ukraine, in L. M. L. Z. Onyshkevych and M. G. Rewakowicz (eds), Contemporary Ukraine on the Cultural Map of Europe (pp. 275-294). London: Routledge.

Tkacz, V. (2006). Poeziya yak tekst dlya teatru [Poetry as a text for theatre], Krytyka. Available at: https://krytyka.com/ua/articles/poeziya-yak-tekst-dlya-teatru. (Accessed 8 May 2020). 
Yurchak, A. (2006). Everything Was Forever, Until It Was No More: The last soviet generation. Princeton: Princeton University Press.

Zabuzhko, O. (2009). The Death of Don Juan: Modernism, feminism, nationalism-rethinking Ukrainian literature, 17th Annual J. B. Rudnyckyj Distinguished Lecture, Manitoba, Canada.

Zabuzhko, O. (1990). Dyrygent Ostann'oyi Svichky: Poeziyi. [The Conductor of the Last Candle]. Kyiv: Rad. pys'mennyk.

Zabuzhko, O. (1996). A Kingdom of Fallen Statues. M. Carynnyk, A. Melnyczuk, M. M. Naydan, et al. (trans.), Toronto: Wellspring.

Zabuzhko, O. (2002). Publicity and media under communism and after: The destruction of privacy. Privacy in PostCommunist Europe, 69(1), special issue of Social Research, 35-47.

Zabuzhko, O. (1995). Reinventing the poet in modern Ukrainian culture. The Slavic and East European Journal, 39(2), 270-275.

Zabuzhko, O. (1985). Travnevyj Inij: Poeziyi. [May Frost: Poems]. Kyiv: Molod.

Zhylenko, I. (1987). Divchynka Na Kuli: Poeriyi [A Girl on a Ball: Poetry], Kyiv: Molod.

Zhylenko, I. (2011). Homo Feriens: Spohady [Homo Feriens: Memoirs]. Kyiv: Smoloskyp.

Zhylenko, I. (1985). Ostannij vulychnyj sharmanshbyk [The Last Street Organ-Grinder]. Kyiv: Rad. Pys'mennyk.

Zhylenko, I. (1990). "In a Country House." translated by Virlana Tkacz and Wanda Phipps, Brama, available at: http://www.brama.com/yara/zhy2.html. (Accessed 8 May 2020).

Citation: Russell, S. J. (2020). Toward a Ukrainian Feminist Poetics: The Last Soviet Poetry of Iryna Zhylenko, Natalka Bilotserkivets, and Oksana Zabuzhko (1985-1991). Feminist Encounters: A Journal of Critical Studies in Culture and Politics, 4(2), 29. https://doi.org/10.20897/femenc/8517

Copyright (C) 2020 by Author/s and Licensed by Lectito BV, Netherlands. This is an open access article distributed under the Creative Commons Attribution License which permits unrestricted use, distribution, and reproduction in any medium, provided the original work is properly cited. 